\title{
A Toothpick Inoculation Method for Evaluating Carrot Cultivars for Resistance to Alternaria radicina
}

\author{
B.M. Pryor, R.M. Davis, and R.L. Gilbertson ${ }^{1}$ \\ Department of Plant Pathology, University of California, Davis, CA 95616
}

Additional index words. black rot, postharvest disease, Daucus carota, disease resistance

\begin{abstract}
The susceptibility of 46 carrot cultivars to infection by Alternaria radicina Meier, Drechsler, and Eddy, causal agent of black rot disease, was evaluated in field trials with a toothpick inoculation method. Toothpicks infested with $A$. radicina were inserted into the shoulders of 10- to 12-week-old carrots (Daucus carota $L$.) and lesion areas were measured 9 to 10 weeks later. There were significant differences in lesion size among cultivars. Relatively resistant cultivars included 'Panther' and 'Caro-pak', and susceptible cultivars included 'Royal Chantenay' and 'Nogales'. Nine of the cultivars were inoculated with $A$. radicina-infested toothpicks and maintained in cold-storage for 10 weeks. Lesion development was greater in cold-storage than in the field, but the relative ranking of cultivars in terms of resistance to $A$. radicina was similar.
\end{abstract}

Black rot disease of carrot, caused by $A$. radicina, occurs in most areas carrots are produced and can cause significant field and postharvest losses (Ellis and Holliday, 1972; Meier et al., 1922). In the field, the disease is characterized by black necrotic lesions on the petiole, crown, and storage root tissue. Under optimal disease conditions, the lesions can expand and coalesce, resulting in collapse of the crop canopy and decay of the storage root. The fungus can also cause damping-off of seedlings, and a blight of foliage and umbels. Umbel infections can result in reduced seed yields and/or fungal-infested seed (Grogan and Snyder, 1952; Maude, 1966; Murtaza et al., 1988; Neergaard, 1945). The planting of A. radicina-infested seed introduces the pathogen into carrot production areas, and is probably responsible for the widespread distribution of the pathogen (Neergaard, 1977; Pryor et al., 1994, 1998; Scott and Wenham, 1972). Once introduced into an area, A. radicina persists in soil for many years and infects subsequent carrot crops (Maude, 1966; Maude and Shuring, 1972; Pryor et al., 1998).

\footnotetext{
Received for publication 11 Aug. 1999. Accepted for publication 5 Jan. 2000. This work was partially supported by the California Fresh Carrot Advisory Board, the Storkan-Hanes Research Foundation, and the College of Agricultural and Environmental Sciences, Univ. of California, Davis. Special thanks are due to Tom Kominek and Richard Webb of the Univ. of California, Davis Plant Pathology field station for maintaining the field plots, and to many of the students in the laboratories of Bob Gilbertson and Mike Davis for their assistance in planting, inoculating, and harvesting the field trials. The cost of publishing this paper was defrayed in part by the payment of page charges. Under postal regulations, this paper therefore must be hereby marked advertisement solely to indicate this fact.

${ }^{1}$ To whom requests for reprints should be addressed.
} E-mail address: rlgilbertson@ucdavis.edu
Postharvest damage caused by $A$. radicina occurs during long-term storage of carrots (Lauritzen, 1926). Although the optimal temperature for growth of $A$. radicina is $28^{\circ} \mathrm{C}$, the fungus can grow at temperatures as low as $0^{\circ} \mathrm{C}$, which explains why the fungus is such an effective postharvest pathogen (Lauritzen, 1926). In 1922, when the fungus was first described, carrot suppliers in New York experienced losses of $>60 \%$ in some lots of stored carrots (Lauritzen, 1926; Meier et al., 1922). In recent surveys conducted in Europe and Asia, the incidence of black rot in carrots held in storage ranged from 0.5 to $50 \%$, which indicates that this remains an important postharvest disease (Geeson et al., 1988; Vlasova, 1990; Vlasova et al., 1988). Maude (1966) demonstrated that carrots infected in the field were the source of inoculum for postharvest infections, and that wounding of healthy carrots during harvesting facilitated infection and spread of the fungus during storage. Thus, management of postharvest losses due to $A$. radicina must begin with disease management in the field.

The management of black rot in the field is difficult for several reasons. Infection often begins on the base of senescing carrot petioles, and the fungus can spread from these initial infection sites to other parts of the plant, as well as from plant to plant. Delivering fungicides to the carrot crown, particularly after the crop canopy has closed, is difficult and generally ineffective. In addition, the ability of $A$. radicina to survive for years in soil requires extended crop rotations to effectively reduce soilborne inoculum levels (Maude, 1966; Maude and Shuring, 1972; Pryor et al., 1998). In some situations, such rotations are not economically feasible.

Cultivars resistant to $A$. radicina infection are a promising tool for improved control of carrot black rot, particularly in soils infested with the fungus. Studies conducted in Europe and Asia have identified resistance to $A$. radicina in carrot germplasm, although no materials were immune (Ivanyuk et al., 1989; Vlasova, 1986; Vlasova et al., 1988). Carrots evaluated in these studies were primarily types favored in Europe and Asia, such as Berlikum, Amarak, Nantes, and Chantenay. Few studies have examined black rot resistance in Imperator-type carrots, which are popular in North America.

The objectives of this work were to evaluate resistance of carrot cultivars to $A$. radicina infection in the field using a toothpick inoculation technique. Imperator-type carrots were primarily evaluated, although several Nantes and Chantenay types were included. A subset of the cultivars used in field trials were also evaluated in cold-storage trials.

\section{Materials and Methods}

Field plot design. Field trials were conducted at the Armstrong Field Station, Univ. of California, Davis campus, in 1995 and 1997. The soil type was Yolo loam (pH 6.5). In each year, the trial was conducted at a different location of the field station. Neither location had ever been planted with carrots. Planting beds were $76 \mathrm{~cm}$ wide. Preplant fertilizer $(16 \mathrm{~N}-9 \mathrm{P}-8 \mathrm{~K})$ was applied at a rate of 184 $\mathrm{kg} \cdot \mathrm{ha}^{-1}$. No other fertilizer or pesticide treatments were applied. Irrigation was supplied by overhead sprinklers.

A randomized complete-block design with four replications was used in all trials. Forty-six carrot cultivars were evaluated, including hybrid and open-pollinated cultivars (Table 1). For each cultivar (plot), $1.5 \mathrm{~m}$ of bed was planted by hand with two rows $15 \mathrm{~cm}$ apart. Planting dates were 23 June 1995 and 6 June 1997. During seed germination, the irrigation frequency was 20 min once or twice per day, followed by $1 \mathrm{~h}$ every other day during seedling growth, and then 4-6 h twice per week after inoculation. During the seedling growth stage, plants were thinned to $\approx 150$ plants per $1.5 \mathrm{~m}$ of bed.

Inoculum production. A. radicina inoculum was prepared on round wooden toothpicks. Toothpicks (250) were bound together in a bundle with a rubber band, and each bundle was placed vertically into a 1 pint (1.9 L) wide-mouth canning jar. Ten milliliters of V-8 juice (Campbell Soup Co., Camden, N. J.) was pipetted over the top of each bundle. The bundle was rolled several times inside the jar to insure uniform wetting, and the jars were autoclaved for $20 \mathrm{~min}$. After cooling, $2 \mathrm{~mL}$ of a suspension of $A$. radicina conidia (isolate BMP 21-21-30, $1 \times 10^{4}$ conidia per $\mathrm{mL}$ ) was pipetted over the top of each bundle. The inoculated toothpicks were incubated for $5 \mathrm{~d}$ at $28^{\circ} \mathrm{C}$ in the dark. For carrot inoculations, only the top end of the toothpick was used.

To confirm that toothpicks were colonized by $A$. radicina, $10 \mathrm{~A}$. radicina-infested toothpicks were stabbed into petri plates of potato dextrose agar (PDA; Difco Laboratories, Plymouth, Minn.). The plates were incubated for $10 \mathrm{~d}$ at $22{ }^{\circ} \mathrm{C}$ under light (Sylvania Cool White, $12 \mathrm{~h}$ light : $12 \mathrm{~h}$ dark cycles). The presence of $A$. radicina was confirmed based 
Table 1. Results of field trials conducted at Davis, Calif., in 1995 and 1997 for evaluation of carrot cultivars for resistance to infection by Alternaria radicina.

\begin{tabular}{|c|c|c|c|c|c|c|}
\hline \multirow[b]{2}{*}{ Cultivar } & \multirow[b]{2}{*}{ Source $^{z}$} & \multirow[b]{2}{*}{ Type $^{y}$} & \multicolumn{2}{|c|}{1995 Lesion } & \multicolumn{2}{|c|}{1997 Lesion } \\
\hline & & & Size $^{x}$ & Rank & Size $^{x}$ & Rank \\
\hline Caro-pak & $\mathrm{AS}(\mathrm{H})$ & I & 1.00 & 1 & 1.87 & 10 \\
\hline Gladiator & FM (H) & I & 1.26 & 2 & 1.68 & 13 \\
\hline Panther & SG (H) & $\mathrm{N}$ & 1.40 & 3 & 0.86 & 1 \\
\hline Caro-spike & $\mathrm{AS}(\mathrm{H})$ & I & 1.44 & 4 & 1.50 & 5 \\
\hline Six-pak II & $\mathrm{HM}(\mathrm{H})$ & I & 1.56 & 5 & 1.08 & 2 \\
\hline Jaguar & $\mathrm{SG}(\mathrm{H})$ & $\mathrm{N}$ & 1.56 & 6 & 1.41 & 3 \\
\hline Orange-strike & $\mathrm{DK}(\mathrm{H})$ & I & 1.57 & 7 & 1.58 & 7 \\
\hline 1934 & $\mathrm{SH}(\mathrm{H})$ & I & 1.63 & 8 & 1.65 & 9 \\
\hline VS 781 & $\mathrm{AB}(\mathrm{H})$ & I & 1.67 & 9 & 2.21 & 20 \\
\hline Aristo-pak & $\mathrm{CR}(\mathrm{H})$ & I & 1.71 & 10 & 1.99 & 15 \\
\hline NVH 1004 & NK (H) & I & 1.75 & 11 & 3.11 & 39 \\
\hline Imperator 58 & $\mathrm{AC}(\mathrm{OP})$ & I & 1.76 & 12 & 2.02 & 16 \\
\hline Dominator & $\mathrm{SS}(\mathrm{H})$ & I & 1.77 & 13 & 2.03 & 17 \\
\hline Six-pak & HM (H) & I & 1.81 & 14 & 1.93 & 14 \\
\hline Caro-choice & $\mathrm{AS}(\mathrm{H})$ & I & 1.86 & 15 & 2.12 & 18 \\
\hline Orange-blitz & DK (H) & I & 1.88 & 16 & 2.31 & 24 \\
\hline Huron & $\mathrm{SS}(\mathrm{H})$ & I & 1.88 & 17 & 1.49 & 4 \\
\hline HMX 5281 & $\mathrm{HM}(\mathrm{H})$ & I & 1.93 & 18 & 1.63 & 8 \\
\hline VS 711 & $\mathrm{AB}(\mathrm{H})$ & I & 1.98 & 19 & 1.55 & 6 \\
\hline FMX 611 & $\mathrm{FM}(\mathrm{H})$ & I & 1.99 & 20 & 2.52 & 27 \\
\hline Pak-mor & HM (H) & I & 2.00 & 21 & 3.08 & 38 \\
\hline Legend & PT (H) & I & 2.07 & 22 & 2.86 & 36 \\
\hline Paydirt & $\mathrm{SH}(\mathrm{H})$ & I & 2.08 & 23 & 2.64 & 31 \\
\hline Avenger & PT (H) & I & 2.11 & 24 & 2.22 & 21 \\
\hline XРH 3726 & $\mathrm{AS}(\mathrm{H})$ & I & 2.14 & 25 & 3.06 & 37 \\
\hline Blaze & NK (H) & I & 2.20 & 26 & 3.95 & 45 \\
\hline Fanci-pak & NK (H) & I & 2.25 & 27 & 2.39 & 25 \\
\hline Sparta & $\mathrm{AC}(\mathrm{H})$ & I & 2.26 & 28 & 3.42 & 41 \\
\hline Navajo & $\mathrm{SS}(\mathrm{H})$ & I & 2.26 & 29 & 2.46 & 26 \\
\hline Plato & $\mathrm{AC}(\mathrm{H})$ & I & 2.33 & 30 & 3.16 & 40 \\
\hline Motherlode & $\mathrm{SH}(\mathrm{H})$ & I & 2.35 & 31 & 2.22 & 22 \\
\hline HMX 5280 & $\mathrm{HM}(\mathrm{H})$ & I & 2.39 & 32 & 2.70 & 33 \\
\hline VS 691 & $\mathrm{AB}(\mathrm{H})$ & I & 2.39 & 33 & 2.74 & 35 \\
\hline Goldmine & $\mathrm{SS}(\mathrm{H})$ & I & 2.43 & 34 & 2.27 & 23 \\
\hline Apache & $\mathrm{SS}(\mathrm{H})$ & I & 2.47 & 35 & 1.77 & 12 \\
\hline Sierra & $\mathrm{NK}(\mathrm{H})$ & I & 2.53 & 36 & 2.18 & 19 \\
\hline CX 7161 & $\mathrm{AC}(\mathrm{H})$ & $\mathrm{I}$ & 2.60 & 37 & 2.63 & 30 \\
\hline Forto & $\mathrm{RS}(\mathrm{H})$ & I & 2.61 & 38 & 1.76 & 11 \\
\hline Caro-best & $\mathrm{AS}(\mathrm{H})$ & $\mathrm{I}$ & 2.63 & 39 & 2.56 & 28 \\
\hline Red-cored Chantenay & $\mathrm{AC}(\mathrm{OP})$ & $\mathrm{C}$ & 2.67 & 40 & 3.45 & 42 \\
\hline$\times \mathrm{PH} 3702$ & AS $(\mathrm{H})$ & $\mathrm{I}$ & 2.79 & 41 & 3.66 & 43 \\
\hline Orlando Gold & $\mathrm{AC}(\mathrm{H})$ & I & 2.80 & 42 & 2.64 & 32 \\
\hline Scarlet Nantes & SG (OP) & $\mathrm{N}$ & 3.01 & 43 & 3.93 & 44 \\
\hline Nogales & $\mathrm{BJ}(\mathrm{H})$ & $\mathrm{I}$ & 3.12 & 44 & 2.73 & 34 \\
\hline Royal Chantenay & $\mathrm{HM}(\mathrm{OP})$ & $\mathrm{C}$ & 3.71 & 45 & 3.97 & 46 \\
\hline 2003 & $\mathrm{SH}(\mathrm{H})$ & $\mathrm{I}$ & 3.81 & 46 & 2.63 & 29 \\
\hline $\mathrm{LSD}_{0.05}$ & & & 0.70 & & 0.99 & \\
\hline
\end{tabular}

${ }^{2} \mathrm{AB}=$ Abbott and Cobb, Inc.; AC = Alf Christianson Seed Co.; AS = Asgrow Seed Co.; BJ = Bejo Zaden Co.; $\mathrm{CR}=$ Crookham Seed Co.; DK $=$ Dakota Seed International, Inc.; FM = Ferry-Morse Seed Co.; HM = Harris Moran Seed Co.; NK = Rogers Northrup King Seed Co.; PT = Petoseed Company, Inc.; RS = Royal Sluis; $\mathrm{SG}=$ Sluis and Groot; $\mathrm{SH}=$ Shamrock Seed Co.; and SS = SunSeeds. $(\mathrm{H})=$ hybrid; $(\mathrm{OP})=$ open-pollinated.

${ }^{\mathrm{y}} \mathrm{C}=$ Chantenay, $\mathrm{I}=$ Imperator, $\mathrm{N}=$ Nantes.

${ }^{x}$ Mean lesion sizes $\left(\mathrm{cm}^{2}\right)$ determined from 40 carrots ( 10 from each of four plots) per cultivar.

upon the diagnostic spore morphology (Simmons, 1995).

Carrot inoculation. Carrots were inoculated 10-12 weeks after planting, when most carrot shoulders were $\geq 15 \mathrm{~mm}$ in diameter. Prior to inoculation, soil on the north side of the planting bed was removed with a hoe to expose the shoulders. Fifteen carrots (shoulders $15-20 \mathrm{~mm}$ in diameter) per plot were inoculated. An A. radicina-infested toothpick was inserted into the shoulder $\approx 10-15$ $\mathrm{mm}$ below the crown and $\approx 5 \mathrm{~mm}$ into the tissue. Care was taken not to insert the toothpick too deeply in order to avoid splitting the carrot. Soil was not replaced around exposed shoulders, and toothpicks were left in place for the duration of the trial. For each plot, two carrots were inoculated with noninfested toothpicks as negative controls. Carrots were inoculated over 2-4 d, and, after the last inoculation of each day, the entire trial was irrigated for $10 \mathrm{~min}$.

Disease evaluation. Carrots were dug 910 weeks after inoculation, and expanding lesions were evident on many of the inoculated roots. Inoculated carrots were recovered from each plot, and ten of these were randomly chosen for lesion size measurements. To estimate the lesion area, a grid of dots $0.5 \mathrm{~cm}$ apart on a $5 \times 7-\mathrm{cm}$ piece of clear transparent paper was placed over the lesion. The numbers of dots that touched the lesion were counted, and this number was divided by four to determine the lesion size in $\mathrm{cm}^{2}$ (Zadoks and Schein, 1979). The average lesion size and coefficient of variation (CV) was determined for each plot.

Cold-storage trials. Nine cultivars were chosen for the cold-storage trials in 1996 and 1997, and represented a range of responses to inoculation with $A$. radicina in preliminary field trials. Plants were collected from plots at the Armstrong field station after $\approx 20$ weeks of growth. Sixteen plants with undamaged storage roots of uniform size and shape were selected per cultivar. The foliage was removed, and storage roots were washed in $0.56 \%$ sodium hypochlorite $(10 \%$ Clorox bleach; The Clorox Co., Oakland, Calif.) for $1 \mathrm{~min}$, rinsed in deionized $\mathrm{H}_{2} \mathrm{O}$ for $20 \mathrm{~s}$, and placed on wire racks in $20 \times 35$-cm plastic boxes with lids. Water was added to each box to a depth of $0.5-1 \mathrm{~cm}$. Carrots were inoculated with $A$. radicina-infested toothpicks as described above. Three replicate boxes, each with five inoculated carrots, were prepared for each cultivar. The remaining carrot was inoculated with a noninfested toothpick as a control. Lids were placed on the boxes, and boxes were arranged in a complete randomized block design on a shelf in a coldroom maintained at $5^{\circ} \mathrm{C}$. After $9-10$ weeks, carrots were washed and lesion growth was measured as described above. The average lesion size and CV was determined for each box.

Statistical analysis. Bartlett's test for nonhomogeneity was used to evaluate homogeneity of variance within each year's trial. A chi-square test for homogeneity of variance between trials was also used to determine if data from the separate trials could be combined in a single analysis. Interaction between year and cultivar, and differences in lesion size were determined by analysis of variance (ANOVA). Separation of means was performed by the least significant difference (LSD) method. Spearman's coefficient of rank correlation was used to evaluate cultivar ranking between the two field trials and between the two cold-storage trials.

\section{Results}

Field trials. In 1995 and 1997, all the inoculated carrots were recovered, except for several plots in which rodents or secondary rot (primarily Sclerotinia sp. and Erwinia sp.) had destroyed some carrots. Inoculated carrots with secondary rots and/or splits that would interfere with accurate lesion measurements were discarded. The average black rot lesion size was $2.1 \pm 0.1 \mathrm{~cm}^{2}$ and $2.3 \pm 0.1$ $\mathrm{cm}^{2}$ for the 1995 and 1997 field trials, respectively. Black rot did not develop in carrots inoculated with noninfested toothpicks, although a small number of these control carrots developed secondary rots (3\%) and splits $(10 \%)$ that initiated from the point of inoculation. Similar results were obtained for inoculated carrots (3\% secondary rots and $18 \%$ splits). The average cVs for the 1995 and 1997 
field trials were $30 \%$ and $33 \%$, respectively.

Bartlett's test revealed nonhomogeneity of variance for lesion size among carrot cultivars for both trials. Therefore, all data were log-transformed, which stabilized variances. Analysis of transformed data by the chi-square test revealed homogeneity of variance between the trials; thus, the data were combined and analyzed for year $\times$ cultivar interaction, which was significant $(P<0.01)$. Therefore, data from each year were analyzed separately to determine differences among cultivars. On each trial's transformed data, ANOVA revealed significant differences $(P<0.01)$ in lesion size among cultivars for both trials (Table 1). Many cultivars performed similarly in both trials. However, for several cultivars, substantial differences in ranking occurred between years (e.g., Forto and NVH1004). The cultivars Caro-pak, Panther, Caro-spike, Six-pak II, Jaguar, Orange Strike, and 1934 consistently ranked among the top 10 cultivars in having the smallest-sized lesions, i.e., the greatest resistance to black rot development (Table 1 and Fig. 1A). In contrast, the cultivars Royal Chantenay, Scarlet Nantes, XPH 3207, Plato, Nogales, and Redcored Chantenay consistently ranked among the 10 cultivars with the largest lesions, i.e., the most susceptible to black rot development (Table 1 and Fig. 1B). Spearman's coefficient of rank correlation was significant $\left(r^{2}=0.661, P<0.001\right)$.

Cold-storage trials. Black rot lesion development was greater in the cold-storage trials than in the field trials. In addition, abundant aerial mycelia developed on the toothpicks and on the surface of the lesions in cold-storage, whereas, in the field trials, the toothpicks and lesions usually appeared dry.

The average black rot lesion size was 10.3 $\pm 0.1 \mathrm{~cm}^{2}$ and $6.2 \pm 0.1 \mathrm{~cm}^{2}$ for the 1996 and 1997 cold-storage trials, respectively. Control carrots inoculated with noninfested toothpicks did not develop secondary rots or splitting, whereas inoculated carrots had $1 \%$ secondary rots and $1 \%$ splits. Average cvs for the 1996 and 1997 cold-storage trials were 33\% and $28 \%$, respectively.

Results from the cold-storage trials were similar to those from the field trials. Bartlett's test revealed homogeneity of variance for lesion size among carrot cultivars for both years. Therefore, no transformation of data was necessary. The chi-square test revealed homogeneity of variance between the trials; thus, the data were combined and analyzed for year $\times$ cultivar interaction. The interaction was significant $(P<0.01)$; thus, data from each year were analyzed separately to determine differences among cultivars. Significant differences $(P<0.01)$ in lesion size among cultivars for both trials were revealed by ANOVA (Table 2). 'Caro-pak' and 'Panther' consistently had the smallest lesions, whereas 'Royal Chantenay' consistently had the largest lesions. However, the ranking of the other six cultivars varied. Spearman's coefficient of rank correlation was significant $\left(r^{2}=0.667, P=0.043\right)$.

HortScience, Vol. 35(6), October 2000

\section{Discussion}

We evaluated the resistance of Imperator type carrot cultivars to infection by $A$. radicina using a toothpick inoculation method. This technique has been used in several other host/ pathogen systems, including corn (Zea mays L.)/Fusarium and soybean [Glycine max (L.) Merr.]/Diaporthe (Calvert and Zuber, 1973; Gilbertson et al., 1985; Hildebrand, 1952;
Keeling, 1982; Young, 1943). In these systems, this technique has been effective and reliable for delivering inocula under field conditions. This is an important consideration for screening for black rot resistance in carrot, particularly in California where summer conditions are hot and dry and field inoculum can quickly die. The toothpick method also provides a means of inoculum delivery that is easy to manipulate in the field.

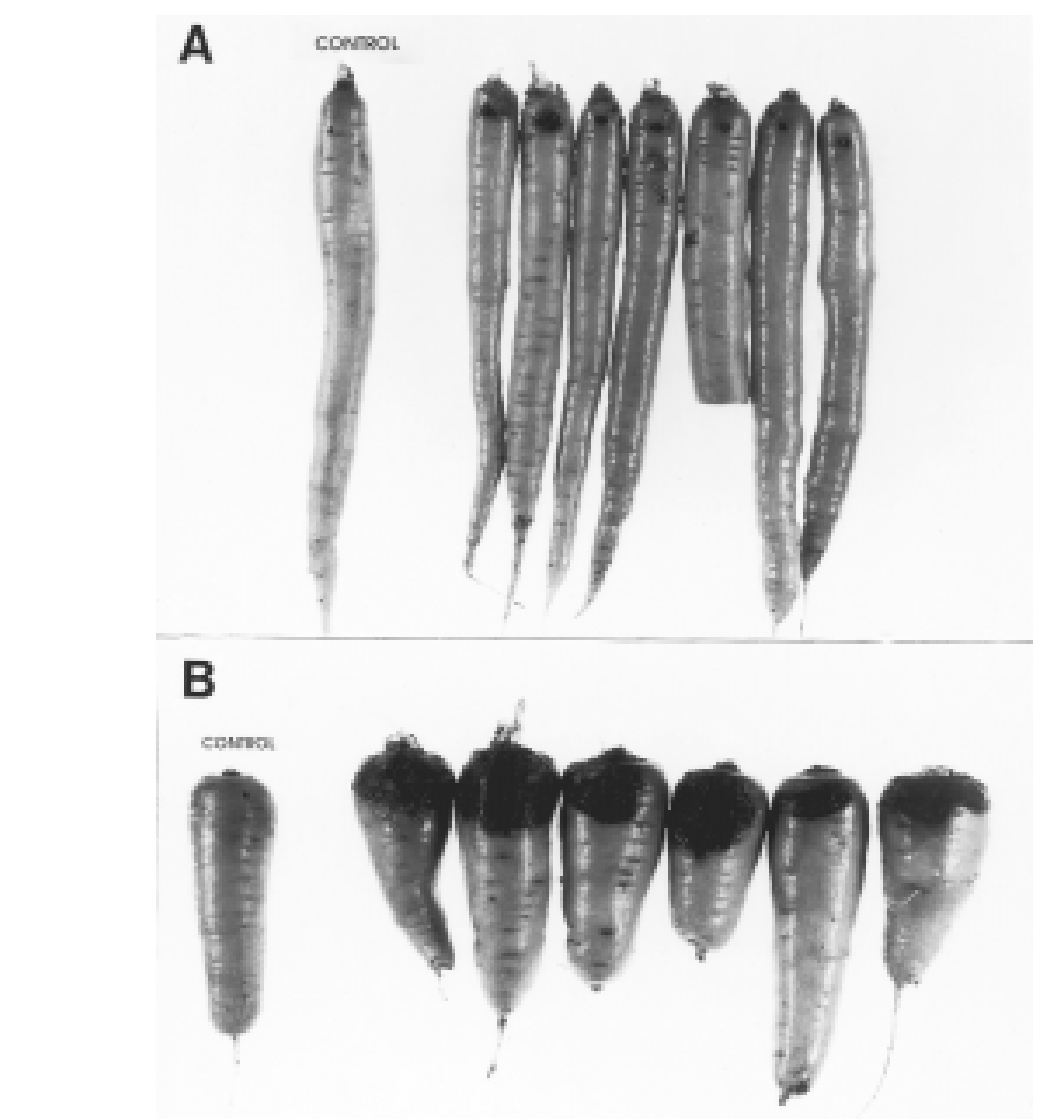

Fig. 1. Responses of (A) 'Caro-pak' (moderately resistant) and (B) 'Royal Chantenay' (susceptible) 10 weeks after inoculation with $A$. radicina-infested toothpicks.

Table 2. Results of cold-storage trials conducted at Davis, Calif., in 1996 and 1997 for evaluation of carrot cultivars for resistance to infection by Alternaria radicina.

\begin{tabular}{|c|c|c|c|c|c|c|}
\hline \multirow[b]{2}{*}{ Cultivar } & \multirow[b]{2}{*}{ Source $^{z}$} & \multirow[b]{2}{*}{ Type $^{y}$} & \multicolumn{2}{|c|}{ 1996 Lesion } & \multicolumn{2}{|c|}{ 1997 Lesion } \\
\hline & & & $\overline{\text { Size }^{x}}$ & $\overline{\text { Rank }}$ & $\overline{\text { Size }^{\mathrm{x}}}$ & Rank \\
\hline Caro-pak & $\overline{A S}(\mathrm{H})$ & I & 2.45 & 1 & 2.50 & 1 \\
\hline Panther & $\mathrm{SG}(\mathrm{H})$ & $\mathrm{N}$ & 2.75 & 2 & 2.62 & 2 \\
\hline Fanci-pak & $\mathrm{NK}(\mathrm{H})$ & I & 5.60 & 3 & 9.35 & 8 \\
\hline Sparta & $\mathrm{AC}(\mathrm{H})$ & I & 5.90 & 4 & 3.82 & 5 \\
\hline Scarlet Nantes & SG (OP) & $\mathrm{N}$ & 6.15 & 5 & 2.75 & 3 \\
\hline Gladiator & $\mathrm{FM}(\mathrm{H})$ & I & 6.32 & 6 & 5.92 & 6 \\
\hline Navajo & SS $(H)$ & I & 7.05 & 7 & 2.85 & 4 \\
\hline Nogales & $\mathrm{BJ}(\mathrm{H})$ & I & 8.80 & 8 & 8.37 & 7 \\
\hline Royal Chantenay & $\mathrm{HM}(\mathrm{OP})$ & $\mathrm{C}$ & 12.40 & 9 & 9.80 & 9 \\
\hline $\mathrm{LSD}_{0.05}$ & & & 8.14 & & 4.28 & \\
\hline
\end{tabular}

${ }^{{ }^{2} \mathrm{AC}}=$ Alf Christianson Seed Co.; AS = Asgrow Seed Co.; BJ = Bejo Zaden Co.; FM = Ferry-Morse Seed Co.; HM = Harris Moran Seed Co.; NK = Rogers Northrup King Seed Co.; SG = Sluis and Groot; and $\mathrm{SS}=$ SunSeeds. $(\mathrm{H})=$ hybrid; $(\mathrm{OP})=$ open-pollinated.

${ }^{y} \mathrm{C}=$ Chantenay, $\mathrm{I}=$ Imperator, $\mathrm{N}=$ Nantes.

${ }^{\mathrm{x}}$ Mean lesion sizes $\left(\mathrm{cm}^{2}\right)$ determined from 15 carrots (three replicates of five each) per cultivar. 
There were significant differences in lesion development among carrot cultivars. Most cultivars performed consistently between trials, as revealed by Spearman's coefficient of rank correlation, suggesting that this method is reproducible. Whether these cultivars show similar responses under field conditions with naturally occurring inocula will be important to determine. Resistance in 'Caro-pak' is interesting because this cultivar is known to be highly susceptible to A. dauci (Kühn) Groves and Skolko, causal agent of Alternaria leaf blight. Different mechanisms may govern resistance/susceptibility to infection of storage root versus leaf tissue by these Alternaria species.

In some cases, cultivar ranking differed between trials. One reason for variability in the responses of certain cultivars to A. radicina inoculation may have been variable environmental factors such as irrigation. High humidity appears to be necessary for optimal disease development. Significant block effects were detected for both field trials and, in all cases, the block with the greatest average lesion size was nearest the proximal end of the irrigation line, whereas the block with the smallest average lesion size was at the distal end. Monitoring irrigation output in each block during fixed periods of irrigation revealed that over $30 \%$ more water was applied to blocks at the proximal end of the irrigation line than to those at the distal end (data not shown).

Further evidence of the critical role of humidity for black rot development came from the storage trials, in which overall lesion development was much greater than in field trials, despite a much cooler incubation temperature. An important difference between the field and cold-storage trials was the high humidity maintained in the plastic boxes used in the latter. The positive effect of the increased humidity on $A$. radicina growth in cold-storage was evident from the abundance of aerial mycelia growing from the infested toothpicks and developing lesions, something that was never observed in the field trials.

In the field, humidity was maintained by frequent sprinkler irrigation, which probably contributed to carrot splitting. The loss of samples due to splitting was substantial in some cultivars, but this was compensated for by inoculating more carrots than were used for evaluation. However, a more effective method of reducing carrot splitting, such as irrigation schedule, the manner in which toothpicks are inserted into carrots, and/or possibly the shape of the toothpick used for inoculation (flat vs. round), is needed. Splitting was not a problem in the cold-storage trials, possibly because the carrots did not grow in storage. Thus, all carrots within each cultivar were relatively uniform in size at the time lesion measurements were taken, as opposed to field trials in which the size varied considerably at the time of lesion measurement. In addition, the surface disinfestation of coldstorage carrots kept secondary rots to a minimum. In general, the cold-storage trials were easier to establish, maintain, and evaluate than were the field trials.

Similar results were obtained in cold-storage trials and field trials, i.e., the most resistant cultivars in the field trials were also the most resistant in the cold-storage trials, and vice versa. This is an important finding because it suggests that results obtained under field conditions may be used as a predictor of resistance to $A$. radicina infection under storage conditions. However, some cultivars did not perform similarly in the field and cold-storage trials. For example, 'Gladiator' was quite resistant to $A$. radicina in the field trials, but only moderately resistant in cold-storage trials. Observed differences in resistance to $A$. radicina infection between field and storage trials may be due to a response to the hypochlorite treatment prior to storage, or to some, yet to be identified, changes in carrot physiology that occur during storage.

In conclusion, this work describes a useful method for evaluating carrot germplasm for resistance to A. radicina under field and storage conditions, and for producing large quantities of uniform black rot inocula for use in carrot cultivar trials. Using this method, we were able to identify differences in resistance to $A$. radicina infection among cultivars and hybrids of the Imperator type carrot. This is the first such evaluation of many of these cultivars for black rot resistance, and the results may be useful for breeders wanting to introduce $A$. radicina resistance into Imperator type carrots. This method should also be useful for further examination of carrot and related germplasm for new sources of resistance to $A$. radicina, as well as for evaluating pathogenicity of $A$. radicina isolates.

\section{Literature Cited}

Calvert, O.H. and M.S. Zuber. 1973. Ear-rotting potential of Helminthosporium maydis race $\mathrm{T}$ in corn. Phytopathology 63:769-772.

Ellis, M.B. and P. Holliday. 1972. Alternaria radicina. No 346. CMI descriptions of pathogenic fungi and bacteria. Commonwealth Mycol. Inst., Kew.

Geeson, J.D., K.M. Browne, and H.P. Everson. 1988. Storage diseases of carrots in East Anglia 197882 , and the effects of some pre- and postharvest factors. Ann. Appl. Biol. 122:503-514.

Gilbertson, R.L., W.M. Brown, Jr., and E.G. Ruppel. 1985. Prevalence and virulence of Fusarium sp. associated with stalk rot of corn in Colorado. Plant Dis. 69:1065-1068.

Grogan, R.G. and W.C. Snyder. 1952. The occurrence and pathological effects of Stemphylium radicinum on carrots in California. Phytopathology $42: 215-218$.

Hildebrand, A.A. 1952. An elaboration of the tooth- pick method of inoculating plants. Can. J. Agr. Sci. 33:506-507.

Ivanyuk, V.G., L.G. Nefedova, and A.V. Sviridov. 1989. Methods and results of evaluating carrot for resistance to dry rots (in Russian with English summary). Nauchno Tekhnicheskii Byulleten' Vsesoyuznogo Ordena Lenina i Ordena Druzhby Narodov Nauchno Issledovatel'skogo Instituta Rastenievodstva Imeni N.I. Vavilova. No. 192:42-46.

Keeling, B.L. 1982. A seedling test for resistance to soybean stem canker caused by Diaporthe phaseolorum var. caulivora. Phytopathology 72:806-809.

Lauritzen, J.I. 1926. The relation of black rot to the storage of carrots. J. Agr. Res. 33:1025-1041.

Maude, R.B. 1966. Studies on the etiology of black rot, Stemphylium radicinum (Meier, Drechsl., \& Eddy) Neerg., and leaf blight, Alternaria dauci (Kühn) Groves \& Skolko, on carrot crops; and on fungicide control of their seed-borne infection phases. Ann. Appl. Biol. 57:83-93.

Maude, R.B. and C.G. Shuring. 1972. Black rot of carrots. Rpt. Natl. Veg. Res. Sta. 20:103.

Meier, F.C., C. Drechsler, and E.D. Eddy. 1922. Black rot of carrots caused by Alternaria radicina N. Sp. Phytopathology 12:157-168.

Murtaza, M., A. Wahid, S. Ali, and A. Nadeem. 1988. Seedling blight of carrots caused by Stemphylium radicinum. Pakistan J. Agr. Res. 9:601-603.

Neergaard, P. 1945. Danish species of Alternaria and Stemphylium. Oxford Univ. Press, London.

Neergaard, P. 1977. Seed pathology, Vol. I. Halsted Press, New York.

Pryor, B.M., R.M. Davis, and R.L. Gilbertson. 1994 Detection and eradication of Alternaria radicina on carrot seed. Plant Dis. 78:452-456.

Pryor, B.M., R.M. Davis, and R.L. Gilbertson. 1998. Detection of soilborne A. radicina and its occurrence in California carrot fields. Plant Dis 82:891-895

Scott, D.J. and H.T. Wenham. 1972. Occurrence of two seed-borne pathogens, Alternaria radicina and Alternaria dauci, on imported carrot seed in New Zealand. N.Z. J. Agr. Res. 16:247-250.

Simmons, E.G. 1995. Alternaria themes and variation (112-144). Mycotaxon 55:55-163.

Vlasova, E.A. 1986. Analysis of the pathogenic mycoflora of carrot and the resistance of its germplasm to the main diseases (in Russian with English summary). Sbornik Nauchnykh Trudov po Prikladnoi Botanike, Genetike, i Selektsii. 102:72-79.

Vlasova, E.A. 1990. Study of multiple infection in Daucus carota $\mathrm{L}$. and selection of sources of resistance (in Russian with English Summary). Sbornik Nauchnykh Trudov po Prikladnolbrli Botanike, Genetike, i Selektsii. 132:82-89.

Vlasova, E.A., L.V. Sazonova, and E.I. Fedorenko. 1988. Immunity analysis of the diversity of Daucus carota $\mathrm{L}$. and patterns in the distribution of resistance to disease (in Russian with English summary). Sbornik Nauchnykh Trudov po Prikladnoi Botanike, Genetike, i Selektsii. 118:14-23.

Young, H.C. 1943. The toothpick method of inoculating corn for ear and stalk rots. Phytopathology 33:16. (Abstr.)

Zadoks, J.C. and R.D. Schein. 1979. Epidemiology and plant disease management. Oxford Univ. Press, New York. 